\title{
A method to detect soil carbon degradation during soil erosion
}

\author{
C. Alewell, M. Schaub, and F. Conen \\ Institute of Environmental Geosciences, University of Basel, Bernoullistr. 30, 4055 Basel, Switzerland
}

Received: 20 May 2009 - Published in Biogeosciences Discuss.: 18 June 2009

Revised: 6 October 2009 - Accepted: 2 November 2009 - Published: 10 November 2009

\begin{abstract}
Soil erosion has been discussed intensively but controversial both as a significant source or a significant sink of atmospheric carbon possibly explaining the gap in the global carbon budget. One of the major points of discussion has been whether or not carbon is degraded and mineralized to $\mathrm{CO}_{2}$ during detachment, transport and deposition of soil material. By combining the caesium-137 $\left({ }^{137} \mathrm{Cs}\right)$ approach (quantification of erosion rates) with stable carbon isotope signatures (process indicator of mixing versus degradation of carbon pools) we were able to show that degradation of carbon occurs during soil erosion processes at the investigated mountain grasslands in the central Swiss Alps (Urseren Valley, Canton Uri). Transects from upland (erosion source) to wetland soils (erosion sinks) of sites affected by sheet and land slide erosion were sampled. Analysis of ${ }^{137} \mathrm{Cs}$ yielded an input of 2 and 4.6 tha $^{-1} \mathrm{yr}^{-1}$ of soil material into the wetlands sites. Assuming no degradation of soil organic carbon during detachment and transport, carbon isotope signature of soil organic carbon in the wetlands could only be explained with an assumed 500-600 and 350-400 years of erosion input into the wetlands Laui and Spissen, respectively. The latter is highly unlikely with alpine peat growth rates indicating that the upper horizons might have an age between 7 and 200 years. While we do not conclude from our data that eroded soil organic carbon is generally degraded during detachment and transport, we propose this method to gain more information on process dynamics during soil erosion from oxic upland to anoxic wetland soils, sediments or water bodies.
\end{abstract}

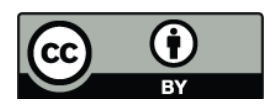

Correspondence to: C. Alewell (christine.alewell@unibas.ch)

\section{Introduction}

The soil organic carbon (SOC) pool contains twice the amount of the atmospheric carbon pool and is thus considered a potential major source to drive global climate change. Soil erosion is the most widespread form of soil degradation and significant amounts of carbon are either relocated to lower situated soils, water bodies and sediments or degraded to $\mathrm{CO}_{2}$ during soil erosion. The latter has been a point of intensive discussion over the last 5 years (Lal, 2004; Lal and Pimentel, 2008; Lal et al., 2004a, b; Harden et al., 2008; Renwick et al., 2004; Smith et al., 2001, 2007; Stallard, 1998; van Oost et al., 2004, 2007, 2008). While some scientists argue that erosion can be considered to decrease carbon stocks in the eroded soils and are thus a $\mathrm{CO}_{2}$ source to the atmosphere (Lal et al., 2004a; Li et al., 2007), others have presented convincing data that most of the eroded soils re-built carbon rather fast up to former carbon contents (van Oost et al., 2004, 2007). Modeling and surveying of carbon contents of alluvial sites and sediments point to carbon accumulation at the erosion sink rather than degradation during detachment and transport of the material (Stallard, 1998; van Oost et al., 2004; Renwick et al., 2004; Harden et al., 2008; Smith et al., 2001, 2007). Whether or not erosion will be a sink or a source for carbon depends on the balance between eroded SOC degradation during detachment and transport, burial of SOC at the erosion sink site and replacement of SOC at the erosion source site. Most modeling efforts were based on rather rough assumptions such as estimated carbon contents (Smith et al., 2007) or the assumption of no SOC degradation during detachment and transport (Stallard, 1998; Smith et al., 2001). Other studies are based upon SOC inventories along eroded soil catena (Beyer et al., 1993; Jacinthe et al., 2001). Experimental studies to assess whether or not SOC is degraded during soil erosion are scarce and have mostly be bound to incubatory studies and $\mathrm{CO}_{2}$ flux measurements under laboratory conditions (Jacinthe et al.,

Published by Copernicus Publications on behalf of the European Geosciences Union. 


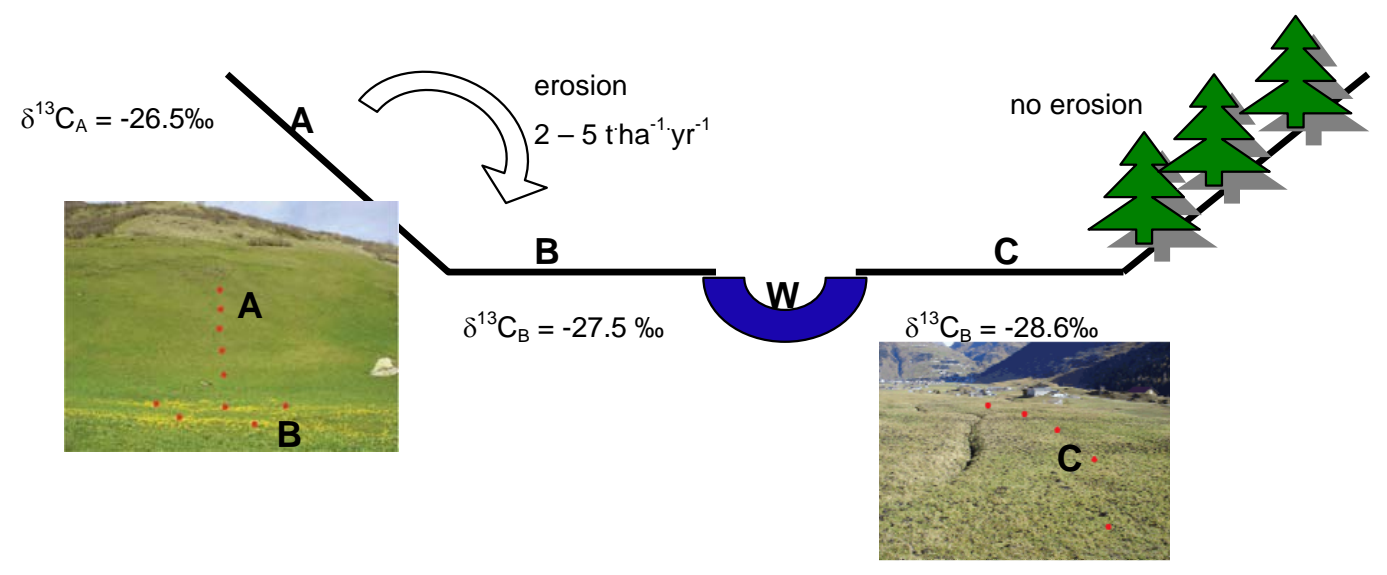

Fig. 1. Concept of tracking down soil erosion with stable isotopic signatures of carbon $\left(\delta^{13} \mathrm{C}\right)$. A=upland (erosion source), $\mathrm{B}=$ wetland (erosion sink), C=reference wetland, W=water body. Data from Schaub and Alewell (2009).

2002; Van Hemelryck et al., 2009). A method of direct evidence whether or not eroded carbon is merely transported to alluvial sites, sediments and/or water bodies and eventually deposited in long term sinks or if it is degraded during detachment and transport is still lacking.

Caesium-137 ( $\left.{ }^{137} \mathrm{Cs}\right)$ has been used widely to quantify soil erosion and sedimentation rates (Walling and He, 1999a, b). The measurement of ${ }^{137} \mathrm{Cs}$ concentrations can provide important information on the extent of soil erosion in areas where ${ }^{137} \mathrm{Cs}$ occurs either due to nuclear weapon testing or the Chernobyl reactor accident in 1986. After deposition, ${ }^{137} \mathrm{Cs}$ is rapidly and tightly bound to the fine particles in the soil. Redistribution is mainly caused by physical processes where ${ }^{137} \mathrm{Cs}$ moves with soil particles (e.g. Ritchie and McHenry, 1990; Bonnett et al., 1990).

Stable isotopes have been successfully used to trace soil erosion and SOC transfer (Buck and Monger, 1999; Papanicolaou et al., 2003; Fox and Papanicolaou, 2007; Alewell et al., 2008; Turnbull et al., 2008; Schaub and Alewell, 2009; Schaub et al., 2009; Jacinthe et al., 2009). Regarding stable carbon isotope signatures, most studies have used the isotopic difference between $\mathrm{C} 3$ and $\mathrm{C} 4$ plants to track soil organic carbon transfer during erosion (e.g. Buck and Monger, 1999; Turnbull et al., 2008; Jacinthe et al., 2009). Few studies assessed soil erosion qualitatively in transects with $\mathrm{C} 3$ plants only using additional information like $\mathrm{C} / \mathrm{N}$ ratios (Papanicolaou et al., 2003) or gradients from oxic upland soils (erosion source) to anoxic wetlands (erosion sink; Fox and Papanicolaou, 2007; Alewell et al., 2008; Schaub and Alewell, 2009). Stable carbon isotope signature of oxic upland and wetland soils have been shown to be significantly different with heavier values in the uplands than in the wetlands (Fox and Papnicolaou, 2007; Schaub and Alewell, 2009; Fig. 1). At the alpine grasslands investigated in this study, the latter was not due to differences in stable isotope signature of vegetation as the input signal to the soils
(Schaub and Alewell, 2009). Rather, the enrichment in upland soils is connected to SOC degradation with preferential turnover of the lighter ${ }^{12} \mathrm{C}$ leaving the remaining SOC pool enriched in $\delta^{13} \mathrm{C}$. In contrast, stable isotope signature of carbon in wetlands soils was very similar to the vegetation signal because of suppressed SOC degradation in these anoxic environments. Wetland soils impacted by sedimentation of eroded material from upland soils have an intermediate stable isotope signature between upland (erosion source) and reference wetland soils (Schaub and Alewell, 2009; Fig. 1).

In a new interpretation of the data set from Schaub and Alewell (2009) we combined the ${ }^{137} \mathrm{Cs}$ approach with the stable isotope approach to quantify eroded SOC and also gain information about possible degradation of eroded SOC during detachment and transport to wetland soils (see concept for details). The aim of this study was to detect whether or not eroded SOC is degraded during detachment and transport at our experimental sites in the Urseren Valley (Canton Uri, Central Swiss Alps), which is heavily affected by sheet as well as land slide erosion.

\section{Methods}

\subsection{Site description}

The Urseren Valley (Canton Uri, Central Switzerland) is a W-E extended mountain valley from approximately $1500 \mathrm{~m}$ above sea level (a.s.l., valley bottom) up to $2500 \mathrm{~m}$ a.s.l. The climate is subalpine to alpine with a mean annual rainfall of $1400 \mathrm{~mm}$ and a mean annual air temperature of $4.3^{\circ} \mathrm{C}$ (meteorological station Andermatt, 1986-2007; Federal Office of Meteorology and Climatology (MeteoSwiss), Switzerland). Upland soils in the study area mainly consist of cambisols, podsols and stagnosols. Histosols and histic to mollic gleysols are found in wetland areas. All wetland soils have 
histic characteristics up to a minimal depth of $20 \mathrm{~cm}$. Dominating land use in the valley is cultivated pastures and hayfields. The valley is strongly affected by soil erosion. For a detailed description of the Urseren Valley see Meusburger and Alewell (2008).

Samples were collected at two erosive grassland sites on the lower southern slopes (between 1500 and $1600 \mathrm{~m}$ a.s.l.) between the villages of Hospental and Realp: Spissen (affected by landslide erosion), and Laui (sheet erosion). Additionally, a reference wetland which is not directly connected to hill slopes was sampled (Oberes Moos). Vegetation of wetland and upland soils did not differ significantly in their $\delta^{13} \mathrm{C}$ values $(-28.7 \pm 0.4 \%$ and of $-28.2 \pm 0.1 \%$, respectively; for a detailed description of vegetation cover see Schaub and Alewell, 2009). Sites are usually fertilized with organic manure once a year. While the latter has a strong effect on $\delta^{15} \mathrm{~N}, \delta^{13} \mathrm{C}$ of the sites were not affected by manuring (Schaub and Alewell, 2009). All sampling sites were at similar altitudes between 1500 and $1550 \mathrm{~m}$ a.s.l. to avoid altitudinal effects on $\delta^{13} \mathrm{C}$ due to changes in mineralisation rates, decomposition or differences in fractionation factors during plant uptake of $\mathrm{CO}_{2}$ at different partial pressures (Schaub and Alewell, 2009).

\subsection{Sample preparation and analysis}

Five samples of $10 \mathrm{~cm}$ depth were analyzed at each site. Inorganic carbon was removed prior to stable isotope analysis by acid fumigation following the method of Harris et al. (2001). Stable carbon isotope analyses were accomplished using a continuous flow isotope ratio mass spectrometer (DELTA ${ }^{\text {plus }}$ XP, Thermo Finnigan, Bremen, Germany) coupled with a FLASH Elemental Analyzer 1112 (Thermo Finnigan, Milan, Italy) combined with a CONFLO III Interface (Thermo Finnigan, Bremen, Germany) following standard processing techniques. Stable isotope ratios are reported as $\delta^{13} \mathrm{C}$ values [\%o] relative to V-PDB defined in terms of NBS $19=1.95 \%$. The long term reproducibility for all standards is better than $0.1 \%$ o (for a more detailed description of sample handling and analysis see Schaub and Alewell, 2009).

\section{$2.3 \quad{ }^{137}$ Cs measurements and calculation of erosionrates}

${ }^{137} \mathrm{Cs}$ was analyzed in soil samples of a depth of $10 \mathrm{~cm}$ as most of the ${ }^{137} \mathrm{Cs}$ is stored in this section (Schimack et al., 1989, Owens et al., 1996, Schoorl et al., 2004; Schaub and Alewell, 2009). Five to nine samples were taken at each hillslope section during summer seasons 2006 and 2007. Depth profiles where determined at the reference wetland $(0-5 \mathrm{~cm}$, $5-10 \mathrm{~cm}, 10-15 \mathrm{~cm}$ and $15-20 \mathrm{~cm})$. Measurements were done with a Li-drifted Ge detector (GeLi; Princeton GammaTech, Princeton, NJ, USA) at the Department for Physics and Astronomy, University of Basel. The resulting measurement uncertainty on ${ }^{137} \mathrm{Cs}$ peak area is lower than $15 \%$.
The use of ${ }^{137} \mathrm{Cs}$ measurements to quantify soil redistribution rates is commonly based upon a comparison of ${ }^{137} \mathrm{Cs}$ inventories for individual sampling points to the local reference inventory. When ${ }^{137} \mathrm{Cs}$ reaches the soil surface by wet deposition, it is tightly adsorbed to fine soil particles. The subsequent lateral redistribution of adsorbed ${ }^{137} \mathrm{Cs}$ is associated with soil erosion (Sawhney, 1972). Erosion is indicated by lower ${ }^{137} \mathrm{Cs}$ values, while sedimentation is indicated by higher ${ }^{137} \mathrm{Cs}$ inventories compared to the reference site. Sedimentation rates $\left(S_{\text {input }}\right)$ were calculated using the profile distribution model (Walling and He, 1999a; Zhang et al., 1990):

$A^{\prime}(x)=A_{\text {ref }}\left(1-e^{-x / h_{0}}\right)$

where $x=$ depth from soil surface expressed as mass of soil per area $\left(\mathrm{kg} \mathrm{m}^{-2}\right), A^{\prime}(x)=$ amount of ${ }^{137} \mathrm{Cs}$ above depth $x$ $\left(\mathrm{Bq} \mathrm{m}^{-2}\right), A_{\text {ref }}=$ local ${ }^{137} \mathrm{Cs}$ reference inventory $\left(\mathrm{Bq} \mathrm{m}^{-2}\right)$ and $h_{0}=$ coefficient describing profile shape $\left(\mathrm{kg} \mathrm{m}^{-2}\right)$ of the depth profile at the reference site. The greater the value of the shape factor $h_{0}$, the deeper ${ }^{137} \mathrm{Cs}$ penetrates into the soil (Walling and He, 1999b). The main ${ }^{137} \mathrm{Cs}$ fallout at our site occurred after the Chernobyl accident in 1986 (Dubois and Cort, 2001). Thus, the total sedimentation $\left(S_{\text {input }}\right)$ at a point can be expressed as (Walling and He, 1999a; Zhang et al., 1990):

$S_{\text {input }}=\frac{10}{t-1986} \ln \left(1-\frac{X}{100}\right) h_{0}$

with $t=$ year of sample collection and $X$ the percentage reduction in total ${ }^{137} \mathrm{Cs}$ inventory (note that in case of sedimentation $X$ is negative).

\section{Concept}

Deposited soil material in wetland soils was quantified with ${ }^{137} \mathrm{Cs}$ (see above). Mass of soil organic carbon (SOC) input to wetland systems can be calculated with \%SOC of adjacent uplands (= erosion source).

$\mathrm{SOC}_{\text {input }}=S_{\text {input }} \cdot \% \mathrm{SOC}_{\mathrm{A}}$

with $\mathrm{SOC}_{\text {input }}=$ mass of SOC deposited at the impacted wetland per year $\left(\mathrm{tha}^{-1} \mathrm{yr}^{-1}\right), S_{\text {input }}=$ yearly soil erosion rates $\left(\right.$ tha $^{-1} \mathrm{yr}^{-1}$ ) and $\% \mathrm{SOC}_{\mathrm{A}}=\mathrm{SOC}$ content of the upland soil (erosion source).

With the assumption that no or only negligible degradation of SOC during detachment and transport is occurring, stable isotope signature of erosion impacted wetland B can be calculated by a mere mixing model approach as:

$$
\begin{aligned}
\operatorname{SOC}_{\mathrm{B}} \cdot \partial{ }^{13} \mathrm{C}_{\mathrm{B}_{\text {calc }}} & =\left(\mathrm{SOC}_{\text {input }} \cdot \text { years } \cdot \partial{ }^{13} \mathrm{C}_{\mathrm{A}}\right) \\
& +\left(\mathrm{SOC}_{\mathrm{C}} \cdot \partial{ }^{13} \mathrm{C}_{\mathrm{C}}\right)
\end{aligned}
$$

with $\mathrm{C}_{\mathrm{B}}=$ mass of SOC and $\delta^{13} \mathrm{C}_{\mathrm{B}_{\text {calc }}}=$ calculated stable carbon isotope signature of wetland $\mathrm{B}$ (erosion sink), 
$\delta^{13} \mathrm{C}_{\mathrm{A}}=$ stable carbon isotope signature of upland A (erosion source), $\mathrm{SOC}_{\mathrm{C}}=$ mass of SOC and $\delta^{13} \mathrm{C}_{\mathrm{C}}=$ stable carbon isotope signature of wetland $\mathrm{C}$ (reference wetland with no influence of erosion). Theoretically, following a mere mixing model concept, mass of soil organic matter at wetland $\mathrm{B}\left(\mathrm{SOC}_{\mathrm{B}}\right)$ should be greater than the reference wetland $\left(\mathrm{SOC}_{\mathrm{C}}\right)$, because it should be the sum of the yearly input of $\mathrm{SOC}\left(\mathrm{SOC}_{\text {input }}\right)$ plus mass of SOC at the reference wetland $\left(\mathrm{SOC}_{\mathrm{C}}\right)$. However, measured $\% \mathrm{C}_{\mathrm{B}}$ is significantly smaller than $\% \mathrm{SOC}_{\mathrm{C}}$ (data not shown, published in Schaub and Alewell (2009)), which is due to sediment input from uplands and/or increased degradation of SOC at wetlands B. However, (again with the assumption that there is no degradation of SOC during detachment and transport of SOC), $\mathrm{SOC}_{\mathrm{B}}$ can be calculated as:

$\mathrm{SOC}_{\mathrm{B}}=\mathrm{SOC}_{\text {input }} \cdot$ years $+\mathrm{SOC}_{\mathrm{C}}$

Replacing $\mathrm{SOC}_{\mathrm{B}}$ in Eq. (2) with Eq. (3) results in:

$\partial^{13} C_{B}=\frac{\text { SOC }_{\text {input }} \cdot \text { years } \cdot \partial{ }^{13} C_{A}+S_{\text {SOC }} \cdot \partial{ }^{13} C_{C}}{\text { SOC }_{\text {input }} \cdot \text { years }+ \text { SOC }_{C}}$

or:

years $=\frac{\operatorname{SOC}_{C}\left(\partial^{13} C_{C}-\partial^{13} C_{B}\right)}{\operatorname{SOC}_{\text {input }}\left(\partial^{13} C_{B}-\partial^{13} C_{A}\right)}$

Equations (4) and (5) can now be used in two ways:

1. We can assume a certain realistic time frame of erosion (e.g. 50 years) which might have influenced the uppermost $10 \mathrm{~cm}$ of wetland $\mathrm{B}$ and insert these numbers of years in Eq. (4). Our hypothesis here would be that the calculated stable carbon isotope signature of the wetland sink $\left(\delta^{13} \mathrm{C}_{\mathrm{B}_{\text {calc }}}\right)$ should be equal to the measured signature $\left(\delta^{13} \mathrm{C}_{\mathrm{B}_{\text {meas }}}\right)$ if there is no degradation of eroded SOC during detachment and transport. Small and/or negligible degradation of SOC should not be measurable.

2. We can insert the measured isotope signal of erosion influenced wetland $\mathrm{B}\left(\delta^{13} \mathrm{C}_{\mathrm{B}}\right)$ into Eq. (5) and calculate the number of years required to explain the measured isotope signal in wetland B.

\section{Results and discussion}

To simulate the measured $\delta^{13} \mathrm{C}_{\mathrm{B}}$ results in $340-400$ and 500-600 years of erosion for the sites Spissen and Laui, respectively (Table 1). Even though the Urseren Valley was already deforested by the Romans a rough 1000 years ago and we can assume significant soil erosion ever since, this does not explain the measured stable isotope signals in the uppermost $10 \mathrm{~cm}$ of the wetlands. Peat accumulation rates of mires, wetlands and bogs in the European Alps have been de-

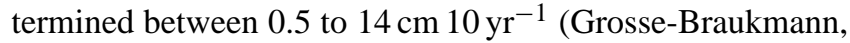

Table 1. Total carbon input $\left(\mathrm{SOC}_{\text {input }}\right)$ and calculated stable isotope values for wetland $\mathrm{B}$ as the erosion sink $\left(\delta^{13} \mathrm{C}_{\mathrm{B}_{\mathrm{calc}}}\right)$ with the assumption of no carbon degradation during erosion. Note that the measured isotopic signal in wetland $\mathrm{B}$ is $\delta^{13} \mathrm{C}_{\mathrm{B}_{\text {meas }}}=-27.0 \%$ and $-27.5 \%$ for Spissen and Laui, respectively.

\begin{tabular}{rrr|rrr}
\hline \multicolumn{3}{c|}{ Spissen } & \multicolumn{3}{|c}{ Laui } \\
\hline & $\begin{array}{r}\mathrm{SOC}_{\text {input }} \\
\text { tha }^{-1}\end{array}$ & $\begin{array}{r}\delta^{13} \mathrm{C}_{\mathrm{B}_{\text {calc }}} \\
\text { years }\end{array}$ & years & $\begin{array}{r}\mathrm{SOC}_{\text {input }} \\
\text { tha }^{-1}\end{array}$ & $\begin{array}{r}\delta^{13} \mathrm{C}_{\mathrm{B}_{\text {calc }}} \\
\% \text { oo }\end{array}$ \\
\hline 0 & 0.0 & -28.6 & 0 & 0.0 & -28.6 \\
50 & 13.6 & -28.1 & 50 & 6.4 & -28.4 \\
100 & 27.1 & -27.8 & 100 & 12.8 & -28.2 \\
200 & 54.3 & -27.4 & 200 & 25.6 & -28.0 \\
300 & 81.4 & -27.1 & 300 & 38.4 & -27.8 \\
346 & 102.0 & -27.0 & 400 & 51.2 & -27.6 \\
500 & 135.7 & -26.9 & 544 & 69.6 & -27.5 \\
600 & 162.8 & -26.8 & 600 & 76.8 & -27.5 \\
800 & 217.1 & -26.7 & 800 & 102.4 & -27.3 \\
\hline
\end{tabular}

1998; Jerz et al., 2000; van der Knaap and van Leeuwen, 2003; Bragazza, 2006), which results in $20-560 \mathrm{~cm}$ of peat accumulation in 400 years. Thus, the investigated $10 \mathrm{~cm}$ of peat in the Urseren Valley have an age between 7 and at the very maximum 200 years. Sediment accumulation during erosion increases "growth" rates of upper horizons which implies that the uppermost $10 \mathrm{~cm}$ are most likely considerably younger than 200 years. With a sedimentation rate of $2-5 \mathrm{tha}^{-1} \mathrm{yr}^{-1}$ and a peat growth rate of $0.05-1.4 \mathrm{~cm} \mathrm{yr}^{-1}$ a decreasing percent of the SOC input term will be retained after several decades or even centuries. The latter undermines our line of argumentation that the differences in stable isotope signal must be due to fractionation during erosion and not due to sedimentation of upland organic carbon over hundreds of years and are obviously not the result of a mere mixing process. Instead, a degradation of eroded SOC and a accompanying fractionation of stable carbon isotopes during detachment, transport and deposition can explain the shift towards heavier $\delta^{13} \mathrm{C}$ signals in wetlands $\mathrm{B}$. The latter results are congruent with experimental evidence from incubation studies of Jacinthe et al. (2002) and Van Hemelryck et al. (2009) who determined up to $37 \%$ and up to $12 \%$ of eroded SOC being degraded to $\mathrm{CO}_{2}$ respectively before $\mathrm{SOC}$ is deposited.

The underlying assumption of our approach is that SOC content and $\delta^{13} \mathrm{C}$ would be the same in wetlands $\mathrm{B}$ and $\mathrm{C}$ if there was no erosion from upland A to wetland B. An alternative explanation for observed SOC contents and $\delta^{13} \mathrm{C}$ values would be differences in water saturation and mineralization between $B$ and C. E.g. if water saturation at wetland C would be more permanent, the lighter $\delta^{13} \mathrm{C}$ (less enrichment in ${ }^{13} \mathrm{C}$ ) might be due to lower decomposition rates compared to wetland B. However, wetland B is situated near the foot of the upland slopes (Fig. 1). Thus, water saturation is nearly 
Table 2. Yearly erosion rates, carbon contents and carbon isotope signatures of the investigated sites. $\rho=$ soil density. A=upland (erosion source), $\mathrm{B}=$ wetland (erosion sink), $\mathrm{C}=$ reference wetland. $\delta^{13} \mathrm{C}$ values with standard deviation $(n=5)$.

\begin{tabular}{|c|c|c|c|c|c|c|c|c|}
\hline & $\begin{array}{l}\text { Erosion rate } \\
\text { tha }^{-1} \mathrm{yr}^{-1}\end{array}$ & $\begin{array}{c}\mathrm{SOC}_{\mathrm{A}} \\
\%\end{array}$ & $\begin{array}{c}\delta^{13} \mathrm{C}_{\mathrm{A}} \\
\% \%\end{array}$ & $\begin{array}{c}\delta^{13} \mathrm{C}_{\mathrm{B}} \\
\% 0\end{array}$ & $\begin{array}{c}\mathrm{SOC}_{\mathrm{C}} \\
\%\end{array}$ & $\begin{array}{c}\rho_{\mathrm{C}} \\
\mathrm{g} \mathrm{cm}^{-3}\end{array}$ & $\begin{array}{c}\operatorname{SOC}_{\mathrm{C}} \\
\text { tha }^{-1} 10 \mathrm{~cm}^{-1}\end{array}$ & $\begin{array}{c}\delta^{13} \mathrm{C}_{\mathrm{C}} \\
\% \circ\end{array}$ \\
\hline Spissen & 4.6 & 5.9 & $-26.2 \pm 0.6$ & $-27.0 \pm 0.6$ & \multirow{2}{*}{34.0} & \multirow{2}{*}{0.15} & \multirow{2}{*}{51.0} & \multirow{2}{*}{$-28.6 \pm 0.5$} \\
\hline Laui & 2.0 & 6.4 & $-26.7 \pm 0.3$ & $-27.5 \pm 0.1$ & & & & \\
\hline
\end{tabular}

permanent throughout the year while wetland $\mathrm{C}$ as the reference wetland is more in the centre of a flat valley bottom protected from sedimentation of eroded material and from water flow from the valley slopes by smaller moraines. Furthermore, we can not exclude that wetland $\mathrm{C}$ has partly been drained. The latter would increase mineralization rates enriching ${ }^{13} \mathrm{C}$ in $\mathrm{SOC}$ of wetland $\mathrm{C}$. Thus, it is more likely that we underestimate calculated years of erosion, which means we underestimate the importance of the degradation of SOC.

Our data show for the investigated slopes in the Urseren Valley that if eroded SOC is not degraded during detachment and transport, we have to assume 340-600 years of erosion to explain measured isotope data. The latter is highly unlikely with peat growth rates indicating that the uppermost $10 \mathrm{~cm}$ of the peats are not older than a maximum of 200 years. We thus conclude for the Urseren Valley that considerable degradation of eroded soil organic carbon during detachment and transport has occurred. However, our aim here is not to prove that soil organic carbon is generally degraded during detachment and transport of soil erosion processes. We are aware that this process will be highly site specific.

Rates of sedimentation $\left(S_{\text {input }}\right)$ were calculated in this study as input of soil material to the wetland sites. However, the amount of eroded material transported is the balance between soil detachment and its retention in upland storage zones (Jacinthe et al., 2009). Konz et al. (2009) estimated approximately $30 \mathrm{tha}^{-1} \mathrm{yr}^{-1}$ as erosion source function of the upland sites investigated in this study. However, calculated sediment deposition rates into the wetlands soils was only between 2-5 tha ${ }^{-1} \mathrm{yr}^{-1}$ (Table 2). Walling (1983) concluded that generally $70-85 \%$ of eroded material remains near the point of detachment. If the major part of the eroded material remains in the upland areas under oxic and thus favorable conditions for SOC degradation, we might assume an even higher SOC degradation.

Soil erosion rates determined with ${ }^{137} \mathrm{Cs}$ are associated with relatively high errors (Walling and He, 1999a, b; Schaub and Alewell, 2009). An assumed error in soil sedimentation rates of $100 \%$ at the sites Spissen and Laui (meaning a doubling of rates) would result in calculated years of erosion of 400 and 200, respectively. Even though this brings us at least for the site Laui closer to realistic growth rates of the peats it still does not explain measured stable isotope signatures of the peats if we assume no soil organic carbon degradation during erosion.

\section{Conclusions}

While our data indicate for the Urseren Valley in the Central Swiss Alps that degradation of soil organic matter occurs during soil erosion, we are fully aware that conclusions will be site specific and can not be extrapolated for quantitative regional or even global conclusions without further investigation. Instead, we aim to propagate a method to close one gap in the so far rather speculative discussion about whether or not soil organic matter is degraded during detachment and transport and the resulting interpretation whether or not soil erosion is a source or sink of atmospheric carbon. We would like to point out that the critical point of our approach is the calculation of ${ }^{137} \mathrm{Cs}$ based erosion rates which are connected to high uncertainties and errors. Being aware of this uncertainty we considered a potential error of $100 \%$ in ${ }^{137} \mathrm{Cs}$ based erosion rates which did not change the main conclusion. In principle, our approach is not bound to ${ }^{137} \mathrm{Cs}$ based erosion rates but could be implemented with modeled erosion rates or rates based on classical surveys. However, even though ${ }^{137} \mathrm{Cs}$ based erosion rates are associated with high uncertainties, they seem to be the best available method in alpine terrain so far.

Acknowledgements. This work was financially supported by the Swiss National Science Foundation (SNF), project no. 200021105579 and 200020-113331. We would like to thank B. Seth for help with the stable isotope measurements and H. Strohm for carrying out the CHN-analyses. Special thanks go to Steven Bouillon and three anonymous reviewers who helped to improve this manuscript. Measurements of ${ }^{137} \mathrm{Cs}$ were done at the Department of Physics and Astronomy, University of Basel.

Edited by: S. Bouillon 


\section{References}

Alewell, C., Meusburger, K., Brodbeck, M., and Bänninger, D.: Methods to describe and predict soil erosion in mountain regions, Landscape Urban Plan., 88, 46-53, 2008.

Beyer, L., Frund, R., Schleuss, U., and Wachendorf, C.: Colluvisols under cultivation in Schleswig-Holstein, 2, Carbon distribution and soil organic-matter composition, J. Plant Nutr. Soil. Sc., 156, 213-217, 1993.

Bonnett, P. J. P.: A review of the erosional behaviour of radionuclides in selected drainage basins, J. Environ. Radioactiv., 11, 251-266, 1990.

Bragazza, L.: A decade of plant species change on a mire in the Italian Alps: Vegetation controlled or climate driven mechanism?, Clim. Change, 77, 415-429, 2006.

Buck, B. J. and Monger, H. C.: Stable isotopes and soilgeomorphology as indicators of Holcene climate change, northern Chihuahuan Desert, J. Arid Environ., 43, 357-373, 1999.

Dubois, G. and De Cort, M. J.: Mapping ${ }^{137}$ Cs deposition: data validation methods and dadta interpretation, J. Environ. Radioactiv., 53, 271-289, 2001.

Fox J. F. and Papanicolaou, A. N.: The use of carbon and nitrogen isotopes to study watershed erosion processes, J. Am. Water Resour. As. (JAWRA), 43, 1047-1064, 2007.

Grosse-Braukmann, G.: The Fünfblänkenmoor at the Engenkopf, a remarkable ombrosoligenous bog in the karst area of the southern Allgäu (Bavarian Alps), Carolinea, 56, 29-62, 1998.

Harden, J. W., Berhe, A. A., Torn, M., Harte, J., Liu, S., and Stallard, R. F.: Soil erosion: Data say C sink, Science, 320, 178-179, 2008.

Harris, D., Horwath, W. R., and van Kessel, C.: Acid fumigation of soils to remove carbonates prior to total organic carbon or carbon-13 isotopic analysis, Soil Sci. Soc. Am. J., 65, 18531856, 2001.

Jacinthe, P. A., Lal, R., and Kimble, J. M.: Organic carbon storage and dynamics in croplands and terrestrial deposits as influenced by subsurface tile drainage, Soil Sci., 166, 322-335, 2001.

Jacinthe, P. A., Lal, R., and Kimble, J. M.: Carbon dioxide evolution in runoff from simulated rainfall on long-term no-till and plowed soils in southwestern Ohio, Soil Till. Res., 66, 23-33, 2002.

Jacinthe, P. A., Lal, R., and Owens, L. B.: Application of stable isotope analysis to quantify the retentsion of erosded carbin in grass filters at the North Appalachian experimental watersheds, Geoderma, 148, 405-412, 2009.

Jerz H., Schneider, T., and Krause, K.-H.: Development of alluvial cones and fans in the periphery of the Murnauer Moos moorland, Geol. Bavarica, 105, 251-264, 2000.

Konz, N., Bänninger, D., Nearing, M., and Alewell, C.: Does WEPP meet the specificity of soil erosion in steep mountain regions?, Hydrol. Earth Syst. Sci. Discuss., 6, 2153-2188, 2009, http://www.hydrol-earth-syst-sci-discuss.net/6/2153/2009/.

Lal, R.: Soil carbon sequestration impacts on global climate change and food security, Science, 304, 1623-1626, 2004.

Lal, R. and Pimentel, D.: Soil erosion: A carbon sink or source?, Science, 319, 1040-1042, 2008.

Lal, R., Griffin, M., Apt, J., Lave, L., and Morgan, M. G.: Managing Soil Carbon, Science, 304, p. 393, 2004a.

Lal, R., Griffin, M., Apt, J., Lave, L., and Morgan, G.: Response to Comments on "Managing Soil Carbon", Science, 305, p. 1567d, 2004b.
Li, X.-G., Li, F.-M., Zed, R., Zhan, Z.-Y., and Singh, B.: Soil physical properties and their relations to organic carbon pools as affected by land use in an alpine pastureland, Geoderma, 139, 98105, 2007.

Meusburger, K. and Alewell, C.: Impacts of anthropogenic and environmental factors on the occurrence of shallow landslides in an alpine catchment, Urseren Valley, Switzerland, Nat. Hazards Earth Syst. Sci., 8, 509-520, 2008, http://www.nat-hazards-earth-syst-sci.net/8/509/2008/.

Owens, P. N., Walling, D. E., and He, Q. P.: The behaviour of bombderived caesium-137 fallout in catchment soils, J. Environ. Radioactiv., 32, 169-191, 1996.

Papanicolaou, A. N., Fox, J. F., and Marshall, J.: Soil fingerprinting in the Palouse Basin, USA using stable carbon and nitrogen isotopes, Int. J. Sed. Res., 18, 278-284, 2003.

Renwick, W. H., Smith, S. V., Sleezer, R. O., and Buddemeier, R. W.: Comment on "Managing soil carbon" (II), Science, 305, p. $1567 \mathrm{c}, 2004$.

Ritchie, J. C. and McHenry, J. R.: Application of radioactive fallout cesium-137 for measuring soil-erosion and sediment accumulation rates and patterns - a review, J. Environ. Qual., 19, 215-233, 1990.

Sawhney, B. L.: Selective Sorption and Fixation of Cations by ClayMinerals - Review, Clay Clay Miner., 20, 93-95, 1972.

Schaub, M. and Alewell, C.: Stable carbon isotopes as an indicator for soil degradation in an alpine environment, Urseren Valley, Switzerland, Rapid Commun. Mass Spectrom., 23, 1499-1507, 2009.

Schaub, M., Seth B., and Alewell, C.: Determination of $\delta^{18} \mathrm{O}$ in soils: measuring conditions and a potential application, Rapid. Commun. Mass Spectrom., 23, 313-318, 2009.

Schimmack, W., Bunzl, K., and Zelles, L.: Initial rates of migration of radionuclides from the Chernobyl fallout in undisturbed soils, Geoderma, 44, 211-218, 1989.

Schoorl, J. M., Boix Fayos, C., de Meijer, R. J., van der Graaf, E. R., and Veldkamp, A.: The Cs-137 technique applied to steep Mediterranean slopes (Part I): the effects of lithology, slope morphology and land use, Catena, 57, 15-34, 2004.

Smith, S. V., Renwick, W. H., Buddmeier, R. W., and Crossland, C. J.: Budgets of soil erosion and deposition for sediments and sedimentary organic carbon across the conterminous United States, Global Biogeochem. Cy., 15, 697-707, 2001.

Smith, S. V., Bullock, S. H., Hinojosa-Corona, A., Franco-Vizaino, E., Escoto-Rodriguez, M., Kretschmar, T. G., Farfan, L. M., and Salzar-Cesena, J. M.: Soil erosion and significance for carbon fluxes in a mountainous Mediterranean-climate watershed, Ecol. Appl., 17, 1379-1387, 2007.

Stallard, R. F.: Terrestrial sedimentation and the carbon cycle: Coupling weathering and erosion to carbon burial, Global Biogeochem. Cy., 12, 231-257, 1998.

Turnbull, L., Brazier, R. E., Wainwright, J., D., Sixon, L., and Bol, R.: Use of carbon isotope analysis to understand semi-arid erosions dynamics and long-term semi-arid land degradation, Rapid. Commun. Mass Spectrom., 22, 1697-1702, 2008.

Van der Knaap, W. O. and van Leeuwen, J. F. N.: Climate-pollen relationships AD 1901-1996 in two small mires near the forest limit in the northern and central Swiss Alps, The Holocen, 13, 809-828, 2003. 
Van Hemelryck, H., Fiener, P., Van Oost, K., and Govers, G.: The effect of soil redistribution on soil organic carbon: an experimental study, Biogeosciences Discuss., 6, 5031-5071, 2009, http://www.biogeosciences-discuss.net/6/5031/2009/.

Van Oost, K., Govers, G., Quine, T. A., and Heckrath, G.: Comment on "Managing soil carbon" (I), Science, 305, p. 1567b, 2004.

Van Oost, K., Quine, T. A., Govers, G., De Gryze, S., Six, J., Harden, J. W., Ritchie, J. C., McCarthy, G. W., Heckrath, G., Kosmas, C., Giraldez, J. V., Marques da Silva, J. R., and Merckx, R.: The impact of agricultural soil erosion on the global carbon cycle, Science, 318, 626-629, 2007.

Van Oost, K., Six, J., Govers, G., Quine, T., and De Gryze, S.: Response to Soil erosion: A carbon sink or source?, Science, 319, p. 1042, 2008.
Walling, D. E.: The sediment delivery ration problem, J. Hydrol., 65, 209-237, 1983.

Walling, D. E. and He, Q.: Improved Models for Estimating Soil Erosion Rates from Cesium-137 Measurements, J. Environ. Qual., 28, 611-622, 1999a.

Walling, D. E. and He, Q.: Use of ${ }^{7} \mathrm{Be}$ and ${ }^{137} \mathrm{Cs}$ measurements to document short- and medium-term rates of water-induced soil erosion on agricultural land, Water Resour. Res., 35, 3865-3874, 1999 b.

Zhang, X. B., Higgitt, D. L. and Walling, D. E.: A preliminary assessment of the potential for using caesium-137 to estimate rates of soil erosion in the Loess Plateau of China, Hydrol. Sci. J., 35, 267-276, 1990. 